\title{
THE EREBUS AND TERROR AT HOBART
}

\author{
BY FRANK DEBENHAM
}

The following notes on the stay of the Ross Expedition in Van Diemen's Land have been prepared from the diaries of Lady Jane Franklin, which were recently bequeathed to the Scott Polar Research Institute under the will of Miss Jessie Lefroy, a niece of Miss Sophia Cracroft. Miss Cracroft was herself the niece of Sir John Franklin and the lifelong companion of Lady Jane.

The ships of the expedition spent, during the ycars 1840 and 1841 , a total of six months in the port of Hobart, then usually called Hobarton, the capital of Van Diemen's Land, of which Sir John Franklin was governor from 1836 to 1844 .

From the pages of Lady Jane's voluminous diaries one can piece together a picture of the society into which the ships' companies were introduced, and a curious picture it is.

A governor, famous in other fields, highminded but perhaps a little rigid, is seen grappling as best he may with intensely local affairs, guided by a curious assortment of councillors.

Nobly but perhaps too actively supported by his wife, especially in matters educational and scientific, we find them meeting with the most distressing hindrances to their highest motives, and leavening but slowly the mixed community of souls with their honourable purposes.

The intolerance they met with over religious questions proved a barrier to a great part of their educational plans and Lady Jane's most cutting remarks are reserved for those who thwarted, on religious grounds, her plans for a college.

Behind the councillors, the military, and the settlers, in oddest contrast of all, there is a background of convicts and bushrangers, of escapes, robberies and murders, though these on the whole figure but lightly in the diaries.

One gains the impression that the dainty ladies of Government House became in time inured to this atmosphere of all degrees of turpitude from mere malfeasance to the blackest crime, and were able either to dismiss a great part of it as beyond their sphere or to view it with a tolerance forced upon them by their strange circumstances. They do not worry 
unduly that their gardener is a murderer, provided that he is a good gardener and has not murdered recently.

The situation is admirably depicted in a sketch, which is published in the Life of Lady Jane Franklin by W. F. Rawnsley, illustrating a visit of the Vice-Regal party to the penal settlement of Port Arthur. The group is inspecting Eaglehawk Neck, a narrow isthmus which was the only possible route of escape to the mainland, and which was therefore guarded by savage dogs chained in a line across the low neck, just within reach of each othcr. The excessively dignified attitude of the Governor, the dainty appearance of his lady and the portentous mien of the officers are in so great a contrast to the line of raging beasts, the lamp posts and the sentries behind them that one would consider it grotesque were it not for the murky figures of some convicts themselves in the background, and the obviously truthful character of the picture.

The bright and, for the nost part, cheerful diaries soon fail to hide the signs of the great strain it must have been for such a couple to govern. a community of which one part was tasting the freedom and independence charactcristic of a pioneer settlement and the other part was bound and shackled by a penal system of extreme severity. That this severity was warranted is shown by the historic fact that at least one bushranger of that period had threatened to take Hobart with his gang, and could have done so had he been able to trust his colleagues. 'The reign of severity by the one side might at any time have given place to a reign of terror by the other.

We can well imagine how the Governor and his wife looked forward to the visit of old friends of the Naval and Arctic service, and how Lady Jane in particular would plan to demonstrate for their judgment her schools and her college, her Royal Society of Science, her schemes of improvement and welfare, even her garden, planned to approxiniate to the stately pleasances of her youth, even to the Greck temple of art, strangely metamorphosed in such a setting to a Museum of Natural History, and not unnaturally displeasing to the rougher of the pioneers and an annoyance to the convicts.

The difficulties confronting any governor in those early colonial days are fully, if trenchantly, illustrated by the remarks of Sir Edward Parry to Sir John Franklin in 1841.

"When first you received the appointment, I did not like to say what I thought, but I do not hesitate to say now, and you are the third Australian Governor to whom I have said it, that the Australian colonies are 
not fit for any gentleman to govern! I dare say you will by this time be ready to echo my sentiments on this head, but this entre-nous...." Lest exception be taken in Tasmania to this quotation, we may add that the same sentiment in other terms was constantly expressed at the time by half the population of the settlement in Van Diemen's Land and indignantly denied by the other half.

It was into such a community of contrasts that there sailed in the middle of August, 1840, the Erebus and Terror, to refit and await the Antarctic season, and in the meantime to make a major magnetic station as base for their observations in the South. Their arrival is first mentioned in the pleasant but very correct style of the diary under the date August 15.

"Captain Moriarty came in, after dinner, habited in his bad weather grcat-coat, announcing the agreeable tidings that the ship which had been signalled was the Terror, Captain Crozier...."

Government House soon has the officers, in twos and threes, to their dinners, and it is in references in the diary to their conversation that one begins to appreciate how great a relief and recreation their visit was to Sir John and Lady Jane. Of these references a few may be quoted for their general interest; thus on the first occasion of their attending a dinner Captain Ross "said he had obtained from the Admiralty everything he asked for, except one, which was a Gunnery Lieutenant he wished to have-Mr FitzJames". Other little items of interest at the same dinner were references to a misunderstanding between Sir John Barrow and Sir John Franklin, and to a sentence in a letter from Major Sabine to Ross in which was the remark that " a better public servant than Franklin does not exist and that in this respect he can compare him to no one better than the Duke of Wellington or something to that effect".

At a dinner a few days later Lady Jane evidently continued the personal conversation thus begun, from which we pick out an item. Captain Ross "said he had been offered knighthood on his return in the 'Cove', but declined it. Afterwards, when Back was knighted he began to feel a little sorry.... Sir John Barrow had been angry with Ross for refusing it and wrote a strong letter to Lord Minto to induce him to renew the offer, but Lord Minto said he had refused it once and must take the consequences... but it would not be refused him if he applied for it; this however Captain Ross did not choose to do." The worldlywise Governor's lady then gives this advice, with what effect we are not told. "...I told him I believed the advantage of accepting a small honor as soon as it was offered was this, that the next time, when fresh honors were deserved, it 
must be a still higher degree which was awarded; thus, if he had been knighted after the return of the 'Cove' the only next thing they could do after his return from the Magnetic Expedition would be to make him a Baronet."

Lady Jane's strong personality and readiness to take unusual means to attain her ends comes out in a further reference to the quarrel between Sir John Barrow and her husband. "I then communicated to Captain Ross my secret of the destruction of Sir John Barrow's letter. Captain Ross said it served Barrow right but I assured him this was by no means my motive, that I was actuated solely by consideration of Sir John's fcelings...." This would appear to savour of interference in a high degree, but she continues, naïvely enough-“"Captain Ross seemed to feel an interest in my story, but I think he thought my action rather a strange one."

And so, in the measured periods and dignified language of an age when diarists were diplomats as well as loving wives, we find many such passages.

She mects, one after another, the various senior officers of the expeclition, and obviously she got on famously with most of them. She was evidently ceaseless in her inquiries of "the Captains" (Ross and Crozier), quoting whom the diary often gives us an interesting appreciation of an individual. For instance, when the Second Lieutenants of the ships, Sibbald and Phillips, were dining at Government House, "I asked Captain Ross if they were at all scientific, but was told not, only very anxious to learn, and that the zcal of his officers knew no bounds". The search for science amongst the officers was partly on behalf of her Science Society, which of course welcomed them as guests. The infinite propriety of these meetings when ladies were present is shown by the remark of "there being shown some drawings and descriptions of the position of the young in the pouch of some marsupial animals, a paper which the gentlemen withdrew to the library to look at".

We may perhaps, too, read into the following the earnest endeavours of the local people to please the magneticians, when in describing the building of the special observatory she says, "the 2 Captains surveyed all with much complacency-the rapidity and ease with which everything is done charms them and exceeds not only what they have met with before, but all that they expected, even from Sir John". This entry is followed by a note on household cares, concerning a French chef, Charles Napoleon by name, who had left her service and was likely to be taken on 
elsewhere; "our convict female has contrived to send us up some very fair dinners, and in an ordinary way does better than Charles. At the same time $I$ thought that if the best French cook in the Colony was in service at all, he ought to be so in the Government House and I rather grudged any lady else engaging him."

Dinners to the officers at Government House continue to alternate with visits of the Franklins and their friends to the magnetic observatory, and these visits promoted the firm friendships which were clearly being formed. One discerns in the diary a tremendous respect for Ross and something perhaps less formal and more companionable towards Crozier.

Thus when the name for the observatory is under discussion and "Gauss Villa" is proposed, Lady Jane writes: "I did not like the skittish(?) title of villa and I also thought it might as well bear the name of Ross as of Gauss, but I could not give utterance to this sentiment in the presence of the hero himself." The friendly relations between Ross and Crozier and perhaps a little teasing of their hostess appear in the next item, "Captain Crozier was away... and Captain Ross told me he would have been full of gratitude, had he seen me, for my present to him (Capt Ross). This was a present of half a lamb.... I sent it to Capt Ross as a novelty but it appears there was a joke afloat, which $I$ had not then heard, that this being Capt Ross' week to purvey for the table, Captain Crozier must try and make as good a dinner as he could at Govt. House for he would get no more during the week, he was always starved when it was Capt Ross' week. The arrival of the lamb immediately after this must of course have looked like a bit of malice on my part but Capt Ross' serious mode of thanking me in Capt Crozier's name did not at all indicate any sense of fun in the matter."

There was a picnic with some of the officers to Lady Jane's "mountain garden" in which Mr Hooker (later Sir Joseph) figures in an amusing incident. "Just after inquiring of Mr Gunn whether he had ever found any snakes here I heard a scream and found him and Mr Hooker bending over the ground. I thought to be sure it was a snake but it was only a new orchis which Mr Hooker had not seen before. A real snake $I$ found had been killed by them some time before." There was a formal dinner on the Erebus for the Franklins and friends. "Sir John went on board in his own boat in his Governor's uniform... the Erebus with her two guns saluted us as we approached and yards were manned; the gun room was used as a drawing room and we sat down 14 to dinner."

Shortly before the time for the expedition to sail, Lady Jane bought 
an island of about 400 acres (Betsey Island, now Franklin Island) in the harbour, and entries in the diary about it give further instance of the warmth of the friendship which had grown up between "the Captains" and Government House. "Captain Crozier and I had already had a good deal of joking about the island which he has taken a great fancy to, and which I had assured him should be transferred to him at the same price I gave for it, provided I got it at all.

"I tried to persuade him I was in earnest as I really was and I was much amused in being able to assure him to-day that the bargain was made. He seems hardly to know what to make of it all, or Captain Ross either, who looks so comically serious and meditative when it is mentioned, that $I$ begin to think he suspects Captain Crozier will desert him when they return from the Magnetic. This at least is a part of the standard joke on the subject."

Then, we may well ask, what is the other part of the standard joke? Lapse of time permits us to do a little intelligent guessing on the mattcr:

There is comparatively little in the diaries about the doings of Miss Sophia Cracroft, who was by all accounts, as well as from the internal evidence of her own letters, a very delightful person. There was even at this stage some kind of attachment on Crozier's part, which certainly increased with the passage of time, and it seems that he proposed to her at least once before the expedition left Van Diemen's Land for the last time. Nor did things run more smoothly for him in this matter when they all met in England again in 1844, for there is an urgent letter from Lady Jane to Ross in which she writes: "There is another subject on which I wish to speak to you but I think it had better not be in writing-it relates to Captain Crozier and Sophy under present circumstances.... I should be glad of your advice.... I wish to tell you what Sophy writes to me on the subject."

I have been told by Miss Lefroy that it was always understood in the family that Crozier wanted to marry her aunt, though there is no further reference to it in the correspondence we have here. In view of these facts and suppositions it is not dificult to conclude that another part of the joke concerning Captain Crozier, Betsey Island and desertion had to do with the very charming niece.of Sir John Franklin.

The diary of Lady Jane had become rather spasmodic at this period and there is nothing in it about the departure of the ships.

Amongst the letters to Ross there is, however, one written by her on 
the day of his sailing which clearly shows that the parting was keenly felt on both sides, and the expressions she uses were as warm as the formal language of the day would permit.

"I think we are not destined to go with you out to sea nor even half way down the river. Sir John does not think it fit for us in this weather ... if this were not perhaps the very last moment I should not tell you that in that inflexibility of purpose of which you gave us so eloquent an expression, ${ }^{1}$ I recognize the noble spirit which has enabled you to do what you have done and will enable you, with God's blessing to persevere thro' a long future career of glorious trials.

"In the perfect conviction that that very strong heart of yours is at all times alive to every generous and amiable affection, $I$ wish you once more affectionately farewell."'

Soon after they had sailed Lady Jane herself had gone off on a journey to New Zealand, and she did not return to Hobart until mid-June of 1841, long after the ships had returned there on April 7, and as they sailed for Sydney on July 7 there was little time, as far as she was concerned, for a renewal of the friendly relations. That they were renewed with the other members of Government House is readily seen from an extract from a letter written by Ross to Franklin from Sydney some few weeks later. In speaking of the kindness met with in Sydney he says: "I reproach myself every moment for ingratitude in the coldness of feeling it excites in comparison with our precious, almost hallowed recollections of Tasmania, for altho' their kindness and attentions have been most unceasing and most cordial we all unite in the old Scotch song, "This is no mine ain Lassie, kind tho' the Lassie be', and regard Hobart as our oron home of the Southern Hemisphere."

How strong were the bonds forged between the Franklins and the other two Captains whilst in Hobart may be seen again in the many letters in our collection from each to other, a correspondence continued long after two of them, Sir John and Captain Crozier, had sailed, in the same two ships, never to return.

We may conclude this footnote to history with a note on the second of "the Captains". Francis Rawdon Moira Crozier entered the Navy in 1810 when he was fourteen years old and was a polar veteran long before his last voyage. He served as midshipman in the Fury under Parry in 1821-23, when he was prominent in the entertainments got up for the men during the winter. He was out again with Parry in the Hecla in

1 In speeches at dinner the previous night. 
1827 on the arduous Spitsbergen voyage. He first served, as First Lieutenant, under James Clark Ross in 1836 in the Cove and sailed with him to the Antarctic in command of the Terror three years later. He was promoted full Captain in 1841 and was still in that rank when he took command of the Terror again in 1845. He succeeded to the command of the Expedition after the death of Sir John Franklin in June 1847 and was in charge of the retreating crews when they landed on King William's Land in April 1848. We are glad to be able to use as our frontispiece a reproduction of his portrait, and to close this article with extracts from his last letter to Sir James Clark Ross, written from the Whalefish Islands in Disco Bay and brought back by the transport, the Barretto Junior, commanded by Licutenant Edward Griffiths.

"My dear James,

"I cannot allow Transport to leave without writing you a line, altho' I have little to say and our many detentions keep me in anything but a fit mood for writing.... How I do miss you-I cannot bear going on board Erebus-Sir John is very kind and would have me there dining every day if I would go.

"All things are groing on well and quietly but we are, I fear, sadly latc.... James, I wish you were here, I would then have no doubt of our pursuing the proper course. I must have done with croaking; I am not growling, mind, indeed I never was less disposed to do so... . Goodsir in Erebus is a most diligent fellow, he seems much in his habits like Hooker, never idle, making perfect sketches of all he collects very•quickly and in the most extraordinarily rough way-he has the happy knack of engaging every one around him in the same pursuit.... All goes on smoothly, but James dear, I am sadly alone, not a soul have I in either ship that I can go and talk to; except to kick up a row with the helmsman or abuse Jobson, at times $\mathrm{I}$ would scarcely even hear the sound of my own voice... I know not what else I can say to you-I feel that I am not in spirits for writing but in truth I am sadly lonely and when I look back to the last voyage I can see the cause and therefore no prospect of having a more joyous feeling."

But, lest Ross should make overmuch of this rather melancholy note he proceeds: "The bustle of the season will however be life to me and come what may I will endeavour to sit down at the end of it content." And so in these last words Crozier exhibits that loyalty to his new but elderly leader and that deep affection for his old and still vigorous leader which seems to have been a chief characteristic of a noble and generous nature. 